\title{
脾炎症性偽腫瘍の 2 例
}

\author{
熊本赤十字病院外科 \\ 平田稔彦山根隆明松金秀暢
}

脾の炎症性偽腫瘍は, 病理組織学的に炎症細胞浸潤と間葉組織の修復に特徴づけられ る腫瘤性病変である. 最近, 第 1 例目は確定診断には至らなかったが, 第 2 例目は初回 例の経験から本症を強く疑い摘脾術を施行した脾原発炎症性偽腫場の 2 例を経験したの で報告する.いずれも自覚症状はなくエコー検診で異常を指摘された. 症例 $1: 79$ 歳,

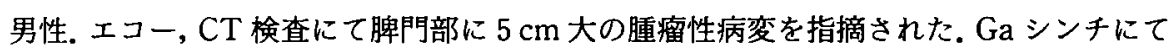
脾に uptake を認めたため悪性リンパ腫を疑い脾摘術を行った. 症例 $2: 67$ 歳, 女性. 3 年間の経過観察中に増大傾向を認めたため手術目的で紹介された。エコー, CT, MRIに て脾下極に $6 \mathrm{~cm}$ 大の腫瘤性病変を認めたが確診に至らず, 第 1 例目の経験と除外診断 より本症を強く疑い手術を施行した。このように本症の存在を念頭において診断を行え ば,ある程度術前診断は可能であると考えられた.

索引用語：脾臟, 炎症性偽腫瘍

\section{緒 言}

脾の炎症性偽腫瘍は, 病理組織学的に炎症細胞浸潤 と間葉組織の修復に特徴づけられる腫瘤性病変であ り，その病因としてはいまだ不明な点が多い。臨床的 には特街的な症状に乏しく脾の孤立性腫瘍として偶然 発見されることがあり，また画像上も所見が一定しな いため術前確定診断は困難で, 血管腫や悪性リンパ腫, 過誤腫などと誤診されやすい.

われわれは第 1 例目は確定診断には至らなかった が, 第 2 例目は初回例の経験から本症を強く疑い摘脾 術を施行した脾炎症性偽腫湯の 2 例を経験したので文 献的考察を加え報告する.

$$
\text { 症例 }
$$

症例 $1: 79$ 歳, 男性.

主訴：自覚症状なし，検診にて指摘。

既往歴, 家族歴：特記事項なし。

現病歴：毎年腹部超音波検診を受けていたが, 今回 初めて脾門部に大きさ約 $5 \mathrm{~cm}$ の腫瘤を指摘され精查 目的で紹介受診となった。

入院時現症および検査成績：眼瞼結膜, 眼球結膜に

2001 年 6 月 4 日受付 2001 年 9 月 4 日採用

〈所属施設住所〉

₹862-8520 熊本市長嶺南 2-1-1
負血, 黄疸は認めず。腹部は平坦, 軟で肝, 脾を触知 せず．表在リンパ節の腫大も認めず．白血球分画にて 好酸球が $7 \%$ と軽度上昇を想める以外に異常を認めな かった。

腹部超音波 (以下 US) 所見：脾門部に $49 \times 40 \mathrm{~mm}$ 大 の辺緑やや不整, 境界明瞭な腫瘤を認めた. 内部エコ 一は不均一で中心部は不整な高エコー，その周囲は低 エコーを呈していた (Fig. 1).カラードップラーでは 腫瘤の辺縁部に血流信号を認め被膜の存在が疑われ た.

腹部 CT 所見：単純 CTでは全体にやゃ low density で, dynamic study $の$ early phase では全体的に 境界明瞭な low densityを示し，その内部は不整に enhance された (Fig. 2).

Ga シンチ所見：脾㵴と思われる部分に肝よりやゃ 低い upake が認められた. 以上より脾悪性リンパ腫を 疑い手術を行った.

手術所見：腹腔内には腹水や腫大したリンパ節は認 めず, 脾門部に約 $5 \mathrm{~cm}$ 大の腫瘤を触知し摘脾術を施 行した。

摘出標本所見 (Fig. 3)：脾淢は重さ $175 \mathrm{~g}$ で, 脾門部 に大きさ $5 \mathrm{~cm}$, 白色調で弾性硬の充実性腫瘤を認め た．境界明瞭で中心部は壊死に陥っていた，組織学的 には線維の増生とリンパ球浸潤からなり, 形質細胞, 


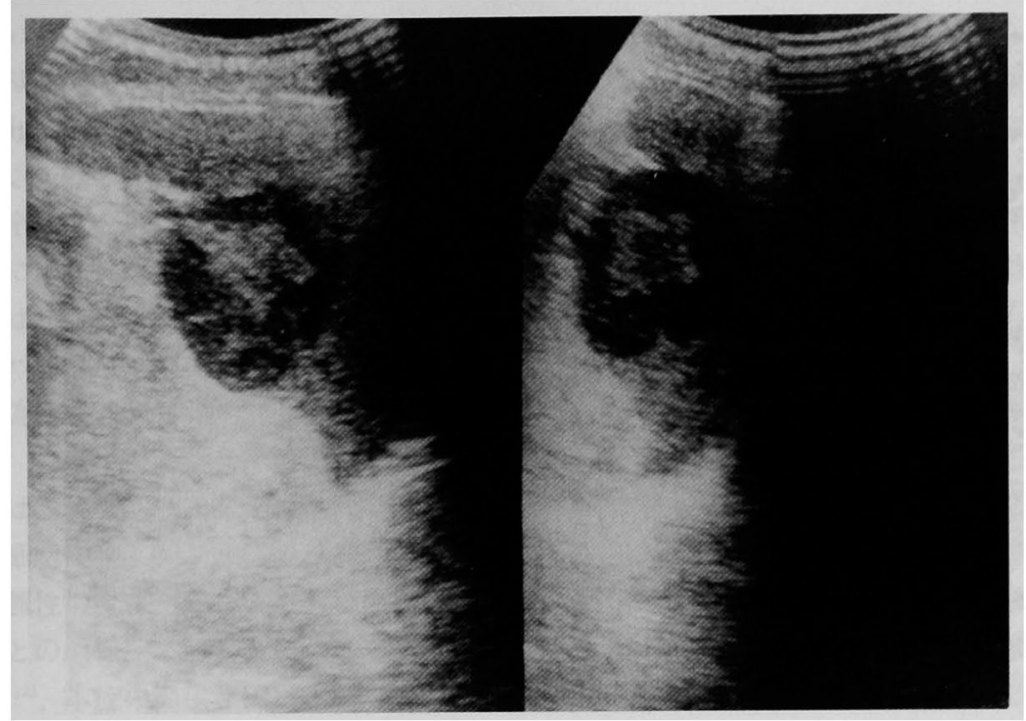

Fig. 1 : Ultrasonography shows a heterogeneous hypoechoic mass in the spleen.

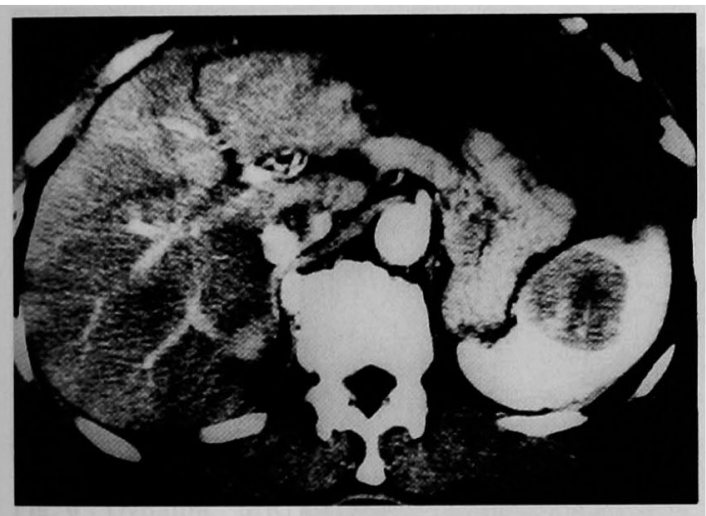

Fig. 2 : The contrast study shows a low-density mass with a clear border in early phase.

好中球，好酸球などの炎症細胞も混在していた，中心 部は凝固壊死と膿場から形成されていた（Fig.4)。以 上より脾炎症性偽腫瘍と診断した。

症例 $2: 67$ 歳, 女性.

主訴：自覚症状なし，検診にて指摘。

既往歴，家族歴：特記事項なし。

現病歴：毎年超音波検診を受けていたが，平成 9 年 の検診にて脾藏に $39 \mathrm{~mm}$ 大の腫瘤を指摘され, USに て経過観察を行っていた。平成12年には大きさ $57 \mathrm{~mm}$ と增大傾向を認めたため，手術目的で紹介となった。

入院時現症および検査成績：身 長 $160 \mathrm{~cm}$, 体 重 54

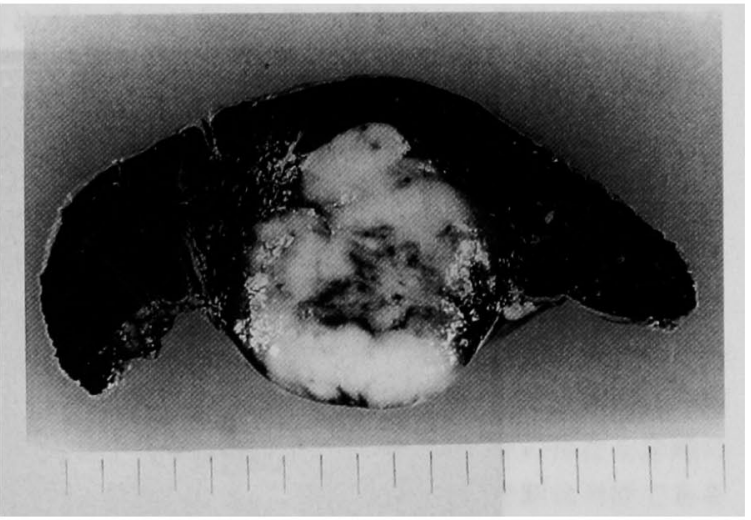

Fig. 3: Cut surface of the resected spleen reveals a whitish mass of $5 \times 4 \mathrm{~cm}$ with necrosis in the center.

kg. 理学所見上異常は認めず. 血算, 血液生化でも異 常所見は認めなかった。

US 所見：脾下極に39mm大の低エコー性腫瘤を認 めた。辺縁はやや不整, 境界は明瞭で内部には一部高 エコー域が存在していた(Fig.5a).カラードップラー では腫瘤内に血流を認め血管に富む腫瘤であることが 示唆された。 3 年の経過で $39 \mathrm{~mm}$ から $57 \mathrm{~mm}$ と增大し ており（Fig. 5b)，悪性腫陽も否定はできなかった。

腹部 CT 所見：病栄は単純 CT では正常部分とほと んど区別がつかず, dynamic study の early phase で 正常脾よりやや low density な部分が不整にみられ， late phase では再び iso density を呈していた。 


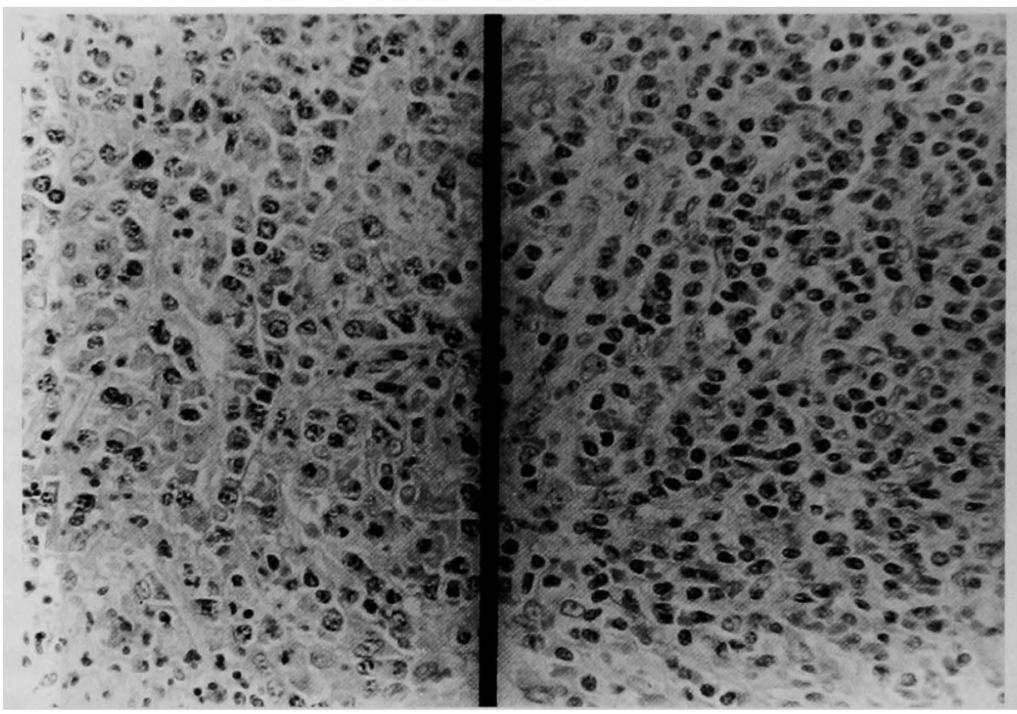

Fig. 4 : Photomicrography shows an increase in fibroblasts and lymphocytes (left), and reveals coagulative necrosis and abscess in the center (right) (Hematoxylin and eosin $\times 400$ ).

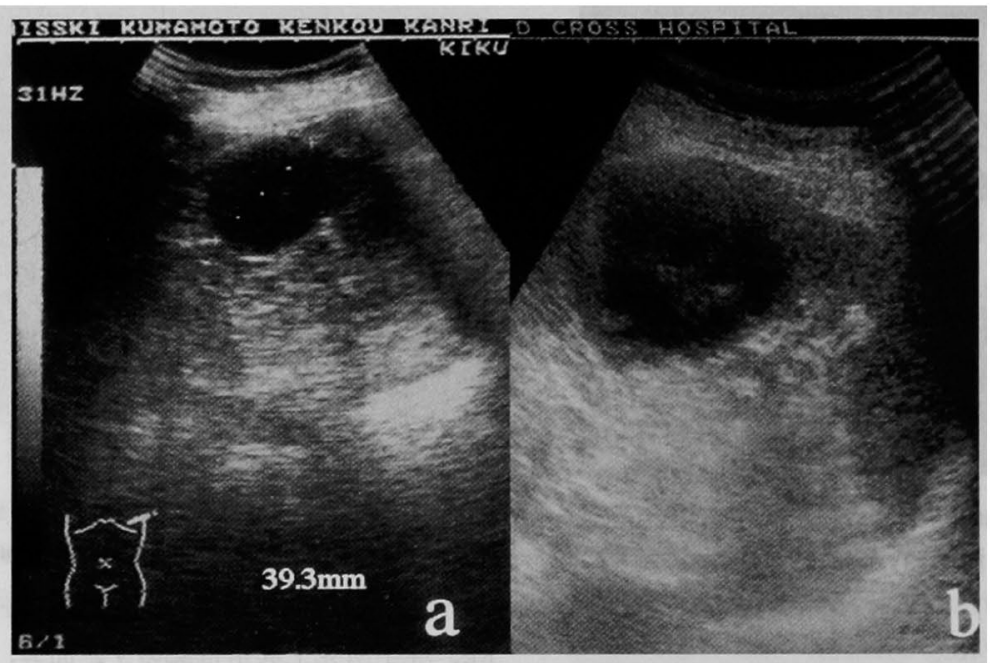

Fig. 5a : Ultrasonography shows the mass of $39 \mathrm{~mm}$ three years before operation.

b : Ultrasonography shows a heterogeneous hypoechoic mass including a hyrerechoic lesion in the spleen.

MRI 所見：T1 強調では正常脾とほほ同等, T2 強 調で low intencity, Gd-DTDA にて正常脾より遅れて ゆるやかに造影された（Fig. 6).Ga シンチでは異常 集積㹥認めずリンパ腫も否定的であった。また転移性 腫場も疑われ全身検索を行ったが，明らかな原発巣を 同定することができず否定的であった。
以上，鑑別診断として血管腫，悪性リンパ腫，転移 性腫瘍や過誤腫などが挙げられたが，全ての検查所見 を満足する診断には至らず除外診断として炎症性偽腫 瘍も念頭におき手術を行った。

手術所見：開腹してみると，脾赛質の腫大はみられ なかったが，大きさ $6 \mathrm{~cm}$ 弾性硬の腫瘤が中下極から 
実質外に突出していた。なお脾周囲リンパ節の腫大や 周囲組織への浸潤は認めず摘脾術を施行した。

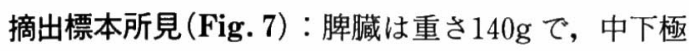
に $6 \times 5 \times 4 \mathrm{~cm}$ 大の充実性の腫瘤を認めた. 脾実質 との境界は明瞭で全体としては白色調で鹃㭔栐を呈して 枋り，内部は所々に斑状の赤色部の混在を認めた。組 織学的にはこの部はリンパ濾胞よりなり, その周辺の 結合織およびリンパ球，形質細胞などの炎症細胞浸潤 が見られ脾炎症性偽腫瘍と診断した。

\section{考 察}

脾炎症性偽腫瘍は, 境界明瞭な腫瘤性病変で, 病理 組織学的には炎症細胞浸潤と間葉組織の修復像を特徵 とし, 辺縁に肉芽腫性の変化を起こす事があり, 炎症 細胞と間葉系細胞との組織反応により多彩な形態を呈 するとされている ${ }^{122)}$. 本症の発生原因は不明であるが 細菌やウイルス感染, 免疫反応, 限局性の出血 ${ }^{233)} と ゙$ が示唆されている.

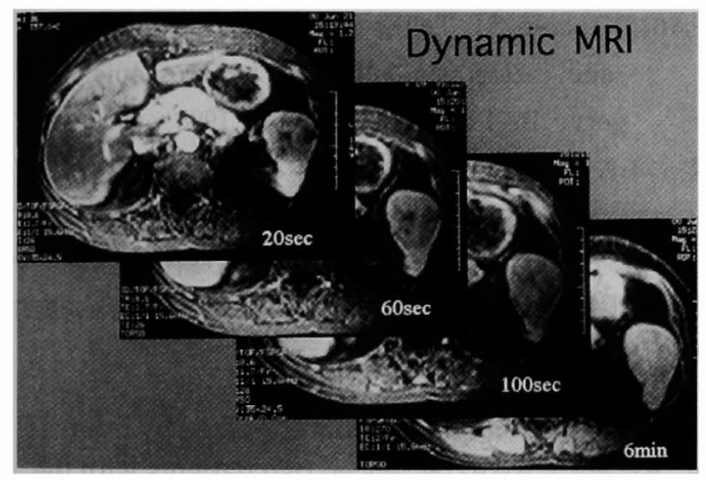

Fig. 6 : Dynamic MRI shows a mild enhancement after administration of Gd-DTPA in the late phase.

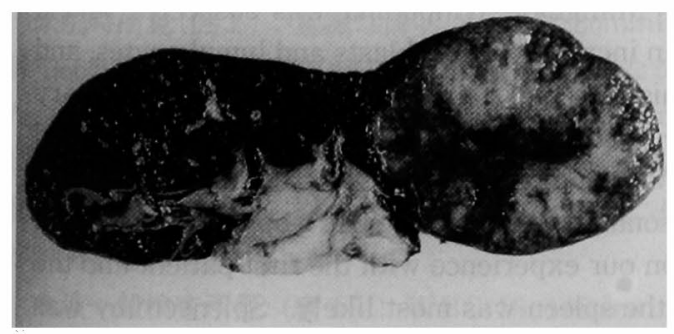

Fig. 7 : A Cut surface of the resected spleen shows a solid and medullary mass of $6 \times 5 \times 4 \mathrm{~cm}$ in diameter with no cyst, necrosis or abscess.
理学所見上, 特徵的な症状に乏しく無症状で, 検診 や他疾患の検索中に脾の孤立性腫瘍として偶然発見さ れる場合も稀ではない4). 有症状でも腹痛, 腹部不快 感など腫大した脾による圧迫症状を呈する程度であ $ろ^{5}$. また画像上も病理組織学的所見を反映し, 特徵と される所見に乏しいため術前確定診断は困難で血管腫 や悪性リンパ腫, 過誤腫などと誤診されることが多い. 最近では症例の蓄積により MRI 所見やUS, 特に力 ラードップラーの有用性なども報告されるようになっ

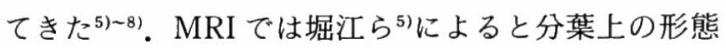
をとる腫瘤内に T2 強調像においてリング状の線状の 低信号がみられ，この部が線維組織の増生部に相当し ていたとしている．典型例では腫瘤の辺緑部の非乾酪 壊死性類上皮肉芽腫と, 中心部の壊死と線維化がみら れるが, 石崎らはこの特徵的所見の 1 つである同心円 状の層構造と, 内部の線維成分を MRI はよく反映し ていると報告している8 . US では Hayasaka ら”によ るとカラードップラーにおいて腫瘍内に血流信号を認 めず，これが本症と他の脾腫瘍との鑑別に有用である としている.

しかしながらわれわれの経験した 2 症例は（症例 1 は MRI 未施行）上述のような MRI 所見やカラードッ プラー所見に合致しておらず，本症の診断の困難さが うかがわれた. 自験例の第 1 例目は US 上, 内部の heterogeneous な所見および Ga シンチ所見から悪性り ンパ腫を第一に疑い手術を施行した。第 2 例目は初回 例の経験を踏まえ除外診断を行った上で，本症も考慮 に入れ手術を行った。このように本症の存在を念頭に おいて診断を行えば，ある程度術前診断は可能である と考えられた。

本症はこれまでに自験例を含め 48 例報告されている が, 確定診断のためには病理組織学的検索が必要であ り,現在までに術前確定しえた症例はみられていない。 本症のように悪性腫場が完全に否定できない場合, 生 検では腫瘍細胞を散布する危険性があるため画像診断 のみで手術に踏み切っているのが現状である.

治療は摘脾のみで予後良好である. 術前確定診断が つけば経過観察でも良いと思われるが自験例(症例 2 ) のように増大傾向の認められるものは破裂の危険性も あり外科的切除が適当と考えられる. 近年, 鏡視下手 術手技の向上により本症に対する腹腔鏡下摘脾術例が 報告されている ${ }^{9)}$. 悪性腫瘍に対する鏡視下手術では port site metastasis の問題が指摘されており ${ }^{10)}$, 本症 の術前確定診断が困難であることを考えるとその術式 
の選択に際しては慎重に対処すべきと思われる。

$$
\text { 結語 }
$$

脾炎症性偽腫瘍の 2 例を報告した。本症は特徴的な 画像所見に乏しく術前診断は困難であるが本性の存在 を念頭において診断を行えば，ある程度は可能である と考えられた。

\section{文献}

1) Dalal $\mathrm{BI}$, Greenberg $\mathrm{H}$, Quinonez $\mathrm{GE}$, et al: Inflammatory pseudotumor of the spleen; Morphological, Radiological, Immunophenotypic, and Ultrastructual Features. Arch Pathol Lab Med 115: 1062-1064, 1991

2）川島邦裕, 小沼英史, 真嶋敏光地：脾原発 inflammatory pseudotumor $の 2$ 例. 日消外会誌 33 ： 357-361，2000

3）藤田佳史, 生駒久視, 中西正芳他：脾の炎症性偽 腫瘍（Inflammatory pseudotumor）の 1 例. 京 府医大誌 $107 ： 703-707,1998$

4）吉岡律子, 三原修一, 田中信次他：超音波検診に て発見された脾腫㾇性病変. 日消集検会誌 36 ： $559-568,1998$
5）堀江靖洋, 平方良輔, 寺坂福治他：脾の Inflammatory pseudotumor $の 1$ 例. 画像診断 $14: 946-$ 950, 1994

6）片桐科子, 西巻 博, 池田俊昭他：脾の inflammatory pseudotumor $の \mathrm{CT} \cdot \mathrm{MRI}$ 所見. 臨放線 39:1635-1638, 1994

7) Hayasaka K, Soeda S, Hirayama M, et al: Inflammatory pseudotumor of the Spleen: US and MRI Findings. Radiat Med 16:47-50, 1998

8）石崎秀幸, 尾崎 裕, 田中慈雄地：脾の inflammatory pseudotumor $の 1$ 例. 臨画像 $11: 90-95$, 1995

9) Kouji T, Hashizume M, Migou S, et al : Laparoscpopic Splenectomy for an Inflammatory Pseudotomor of the Spleen: Operative Tech. nique and Case Report. Hepato-Gastroenter. ology 45 : 1887-1891, 1998

10) Neuhaus SJ, Texler M, Hewett PJ, et al : Port -site metastasis following Laparoscopic surgery. Br J Surg $85: 735-741,1998$

\title{
TWO CASES OF INFLAMMATORY PSEUDOTUMOR OF THE SPLEEN
}

\author{
Toshihiko HIRATA, Takaaki YAMANE and Hidenobu MATSUKANE \\ Department of Surgery, Kumamoto Red Cross Hospital
}

Inflammatory pseudotumor of the spleen is a tumorous lesion histologically characterized by infiltration of inflammatory cells and repair of interstitial tissue. Recently we experienced two patients with the disease, including the first patient in whom we failed to make the preoperative diagnosis and the second patient in whom the experience with the first patient led us to have a strong suspicion of the disease before a splenectomy. In both patients, an asymptomatic splenic mass was incidentally detected by an abdominal ultrasonography (US) at a medical check-up. The first patient was a 79-year-old man, whose abdominal US and CT revealed a solitary mass $49 \times 40 \mathrm{~mm}$ in size in the splenic hilus. Gallium Scintigraphy showed uptake in the mass of the spleen. Malignant lymphoma was suspected and a splenectomy was performed. Photomicrography showed an increase in fibroblasts and lymphocytes, and coagulative necrosis in the center. The tumor was histologically diagnosed as an inflammatory pseudotumor of the spleen. The second patient was a 67 -year-old woman, who was incidentally found to have a splenic mass on abdominal US 3years earlier. Abdominal US was performed once a year and the splenic mass was found growing. CT and magnetic resonance imaging revealed a splenic mass $50 \mathrm{~mm}$ in diameters, but no definite diagnosis was made. Based on our experience with the first patient and the diagnosis by exclusion, an inflammatory pseudotumor in the spleen was most likely. Splenectomy was performed and the tumor was histologically diagnosed as inflammatory pseudotumor of the spleen. It may be possible to make the preoperative diagnosis of the disease to some degree, if the presence of it is kept in mind like in the second patient. 